\title{
Reconstructing time and diagenesis of limestone-marl alternations from the selective compaction of colonies of the tabulate coral Halysites
}

\author{
Theresa Nohl \& Axel MunneCKe
}

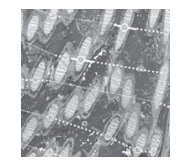

\begin{abstract}
Limestone-marl alternations are often interpreted to reflect cyclic changes in the depositional environment, with time spans for the deposition of a limestone-marl couplet between thousands and tens of thousands of years. Data from halysitid coral colonies from Gotland (Silurian), Sweden, indicate a diagenetic origin of limestones and marls indifferent to original sedimentary differences. The specimens crosscut several layers of their surrounding limestonemarl alternation, which means that both limestone and marl layers are among corallites and surrounding the coral colony. We analysed thin sections, SEM samples and micro-CT scans from Halysites catenularius from Gotland to document (1) the spatial extent of corals, limestone, and marl, and (2) the chronological order of sedimentation and subsequent diagenesis. Our results indicate a sedimentary infill of the coral frame while the coral was still alive. Growth banding indicates growth rates of $3.8 \mathrm{~mm}$ per year. Early diagenetic mass loss by aragonite dissolution as well as sedimentary overburden during progressive burial caused the compaction in marl beds fragmenting the coral, whereas it is well preserved in the limestone beds. The time span of a limestone-marl couplet penetrating the colony lies in the order of a few decades. Thus, the missing time in the depositional record is rather reflected by hiatuses than condensed sedimentary cycles. The mismatch of environmental changes recorded in the coral colonies with the changes in lithology, and the spatial heterogeneity of sedimentation rates within one bed imply constraints for applying lithological changes in cyclostratigraphy. Key words: early diagenesis, cyclostratigraphy, preservation bias, environmental reconstruction, taphonomy.
\end{abstract}

\begin{abstract}
Nohl, T. \& Munnecke, A. 2019. Reconstructing time and diagenesis of limestone-marl alternations from the selective compaction of colonies of the tabulate coral Halysites. Bulletin of Geosciences 94(3), 279-298 (15 figures, 2 tables). Czech Geological Survey, Prague. ISSN 1214-1119. Manuscript received March 12, 2019; accepted in revised form July 24, 2019; published online September 30, 2019; issued November 30, 2019.
\end{abstract}

Theresa Nohl \& Axel Munnecke, Friedrich-Alexander University Erlangen-Nuremberg, GeoZentrum Nordbayern, Loewenichstrasse 28, 91054 Erlangen, Germany; theresa.nohl@fau.de

Stratigraphy, and especially cyclostratigraphy, uses rhythmically alternating lithologies for analysing and dating time span and causes of changes in the depositional environment. The approximate time span of individual beds and couplets are a basic requirement for finetuned cyclostratigraphy based on lithological changes. Limestone-marl alternations are often used for this kind of approach, even though correlation of individual limestonemarl couplets over long distances have been questioned in the last 25 years by studies investigating their specific diagenetic processes (among others Munnecke \& Samtleben 1996; Böhm et al. 2003; Westphal et al. 2010, 2015; Bádenas et al. 2012; Gygi 2012; l'Heureux 2018).

As the precise duration of the deposition of a single bed normally cannot be determined, the temporal range of the whole succession is usually divided by the number of couplets (Schlager et al. 1998). The resulting time span of single beds/couplets thus varies from several 1000 (e.g. millennial cycles) to several 100,000 (Milankovitch cycles) years (Hilgen et al. 2003; see compilation in Strasser et al. 2006). Several problems, however, arise through this method. Apart from hiatuses and the difficulty of defining the precise age of a couplet, fluctuating sedimentation rates are a further limiting factor for any fine-tuned resolution (Sadler 1981). Sadler (1981) and later Schlager et al. (1998) formulated a dependence of the calculated sedimentation rate on the length of the observed interval, with a reduced rate from larger observation intervals (Sadler effect). Or, in other words: "We invariably find that the rock record requires only a small fraction, usually 1 to 10 per cent, of the available time, even if we take account of all possible breaks in the sequence" (van Andel 1981), which means that more than $90 \%$ of the time is not recorded in the respective sediments, not even in the deep sea. So how do we know if this missing time is still reflected in the cyclicity (e.g. only $10 \%$ of every climatic cycle is recorded)? Or is the missing time rather reflected in a lack of an unknown 
number of cycles? This, however, would make a big difference for any frequency analysis. Another potential source of error might be introduced by misidentifying or overlooking the diagenetic processes, either early or late, which overprinted all classical limestone-marl alternations (see review in Westphal 2006). Climatic cycles do exist, and identification of the underlying astronomical cycles in the sedimentary record can produce reliable results (e.g. Langereis \& Hilgen 1991, Da Silva 2013). However, as early as 1958, Sujkowski wrote that "not all series of alternating beds of soft and hard limestone are developed only during diagenesis, but primary rhythm of this type are rarer than usually believed. [...] Probably most of rhythm seen in stratified rocks is partly or completely of diagenetic origin." And Westphal et al. (2015) showed an example of turbiditic sediments that were diagenetically transformed into limestones and marls oblique-angled to the depositional surface. Nohl et al. (2019) provided an example of lithification in which the deposits of a single storm event morphed into both marl and limestone. In both examples, the process generating the limestone-marl alternation was identified as early diagenetic carbonate redistribution by aragonite dissolution and reprecipitation as calcite (Munnecke $\&$ Samtleben 1996), a process called "differential diagenesis" (Westphal et al. 2015, Nohl et al. 2019). It seems that lithification of single beds does not necessarily require specific sedimentary properties (Hallam 1986, Böhm et al. 2003, l'Heureux 2018) because strongly differing primary sediments can be united in a single lithified bed (e.g. mudstone and rudstone) underand overlain by uncemented marl (Munnecke 1997; Westphal et al. 2008, 2015; Nohl et al. 2019). This would not be expected if diagenesis strictly followed sedimentary parameters. The question remains, what is the steering mechanism of selective cementation and dissolution?

In this study, we present an example of coral colonies with a surrounding limestone-marl alternation. The example provides both a cyclic change in lithology and a record of changes in the depositional environment with a relative timeframe deduced from the coral's life span. These coral buildups represent special reeflike deposits that can be called filled frame reef after Riding (2002). The peculiarity of these coral buildups is that they crosscut several layers of their surrounding limestone-marl alternation, which means that some parts of a coral colony are filled with limestone or have marl interbeds. The growth of reef builders can be irregularly interrupted when conditions become unfavourable, e.g. by higher sediment input, lower nutrient supply, sunlight fluctuations or changes in the sea surface temperature (among others Ma 1958, Cruz-Piñon et al. 2003, Young \& Kershaw 2005).

The samples studied here represent special types of reefal buildups, which are associated with a limestone- marl alternation or, respectively, marl interbeds. Thus, their significance for reefs in general is, due to the high variety of reef types, limited (see compilation in Riding 2002). But as the corals serve as a framework for the surrounding limestone-marl alternation, they have witnessed their depositional development as well as their skeleton might give hints on the diagenetic development. The samples were taken from the Silurian of Gotland (Sweden). The prevalent halysitid corals grew on soft substrate, with only a small part protruding out of the sediment, and the coeval background sediments being baffled in between the corallites (Lee \& Elias 1991, Calner et al. 2000, Liang et al. 2016). The samples were studied in terms of coral growth (including growth banding), interruption of coral growth and breakage, and finally compared with the embedding lithology to answer the following research questions: (1) How much time is recorded by the coral colony and how does this compare to a single limestone-marl couplet that penetrates through the coral colony as well as the couplets outside the colonies, (2) how does the sedimentbaffling coral influence the distribution of limestone and marl, and (3) how well are events, which are recorded in the coral skeletons, displayed by changes in lithology?

\section{Geological Background}

\section{Lower Visby Formation in Ireviken (Gotland)}

The first sample set was taken from the Halysites biostrome in Ireviken (Gotland, Sweden, 57 50' 37.3' N, $18^{\circ} 34^{\prime}$ $15.5^{\prime \prime}$ E) (Fig. 1). The sediments are late Llandovery in age (lower Silurian) and are well studied in terms of their biogenic compounds, depositional environment, and isotopic composition (Manten 1971, Stel 1978, Nield 1982, Kershaw 1994, Samtleben \& Munnecke 1999, Calner et al. 2000, Berkowski \& Zapalski 2018). Manten $(1962,1971)$ erroneously attributed the deposits to the Upper Visby Formation. However, the boundary between Lower and Upper Visby Formation is characterised by a turnover in the conodont fauna (Jeppsson 1983), the disappearance of the small rugose coral Palaeocyclus porpita (Hede 1921), and a mass occurrence of the large rugose coral Phaulactis angusta in the lowermost Upper Visby Formation (Samtleben et al. 1996, Adomat et al. 2016), known as the 'Phaulactis layer'. This layer correlates with the onset of a strong positive $\delta^{13} \mathrm{C}$ excursion called the Ireviken excursion (Samtleben et al. 1996, Adomat et al. 2016). Based on the stable carbon isotope values of $+1.4 \%$ (Samtleben et al. 1996) and the finding of the Phaulactis layer about $9 \mathrm{~m}$ above the base of the section (own observation), the Halysites biostrome clearly belongs to the Lower Visby Formation. The sampled interval is described as a halysitid autobiostrome that formed below 


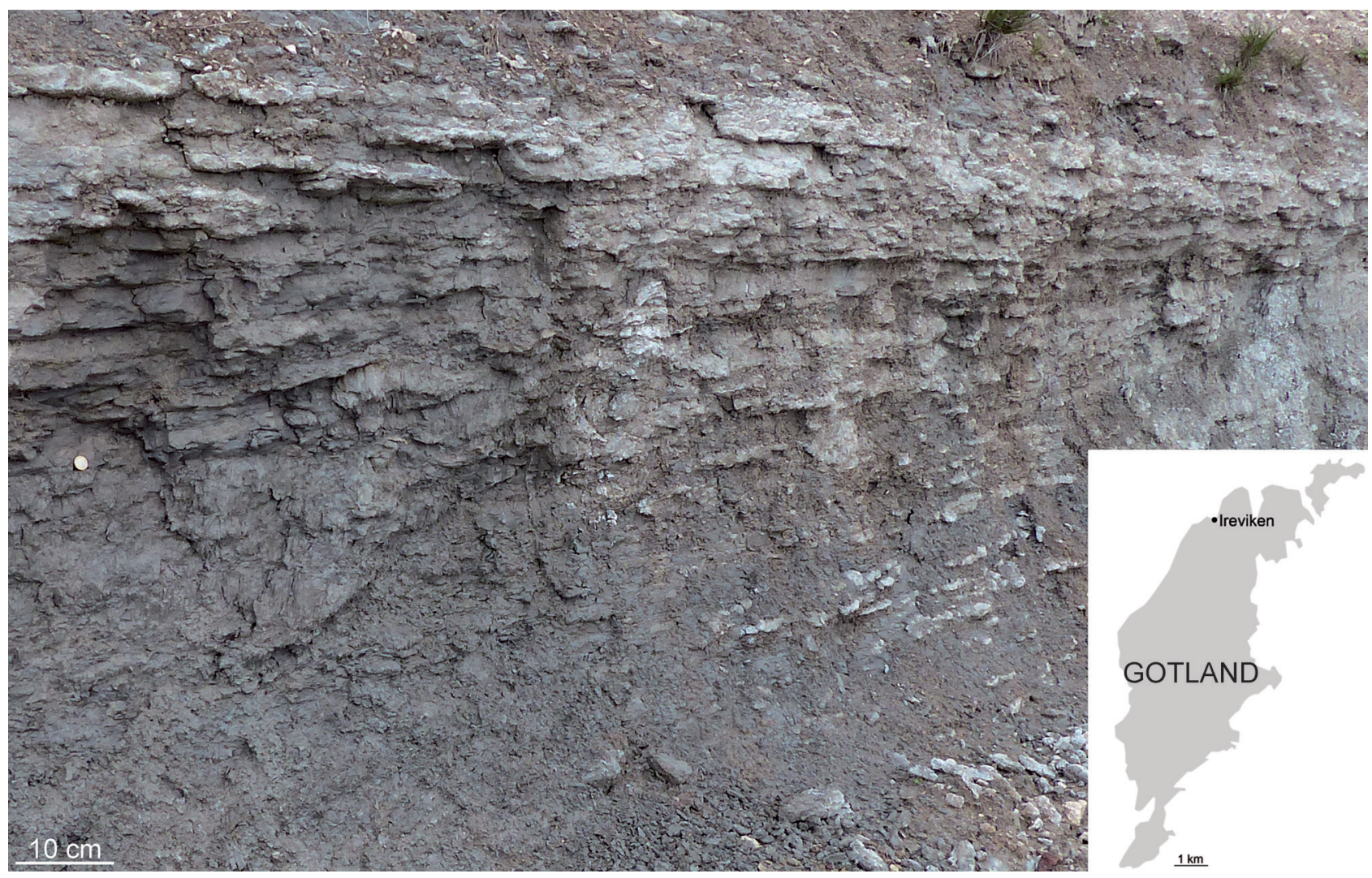

Figure 1. Outcrop picture of the up to one metre thick an several hundred metres long Halysites biostrome and its surrounding limestone-marl alternation of the Lower Visby Formation at Ireviken (Gotland, Sweden).

the storm wave base in a calm environment that can be defined as a platform slope (Kershaw 1994, Samtleben \& Munnecke 1999, Berkowski \& Zapalski 2018). It continues over several hundred metres with a thickness of up to one metre. The biostrome is composed of halysitid (Halysites catenularius), heliolitid and favositid corals, but also of rugose corals (mostly Cystiphyllum visbyense). Fragments of trilobites, brachiopods and echinoderms are found throughout the outcrop, but are enriched in several thin layers.

\section{Material and methods}

In Ireviken (Gotland), three contiguous samples were taken, from which thin sections and micro-CT scans were produced.

The thin sections were studied in terms of the matrix composition, compaction, the growth periodicity of the corals, and their growth interruptions. From the growth periodicity derived from density bandings, the life span of the corallite was calculated. For the determination of the matrix, a scanning electron microscope (Vegal|XMU) was used. Cathodoluminescence was used to identify different cement generations within the corallites, utilising a Technosyn stage. The micro-CT scans, produced in a phoenix v|tomex $\mid \mathrm{x} \mathrm{s}$, were used to document the spatial distribution of broken and unbroken parts of the coral colonies. The micro-CT scans are due to file size available on request from the authors.

\section{Results}

\section{Deep-water biostrome from Ireviken, Lower Visby Formation, Gotland}

The samples from the Halysites biostrome can be divided into the prevalent limestone and thin marl interbeds (Fig. 2A). Both limestone and marl contain abundant halysitid and favositid corals in life position (Fig. 2), as well as small fragments of brachiopods, trilobites, crinoids, and less abundant bryozoans (Fig. 2B). Rugose corals as reported by Berkowski \& Zapalski (2018) from this section were not present in these samples. The matrix is micritic, and cements are normally absent, except for fillings of corallites (Fig. 3A, B), though in the limestone some cavities are filled with blocky calcite spar. Cathodoluminescence analysis revealed 3 to 4 cement generations within the halysitid and the favositid corallites 
in both limestone and marl areas (Fig. 3C-F). While the limestone matrix is slightly luminescent (Fig. 3C), the marl matrix is not (Fig. 3D), except for a very thin rim around corallites that have been filled with calcite spar (Fig. 3D).

The halysitid coral is well preserved in the limestone but commonly broken in the marl. The former continuation of the corallites through the marl is clearly visible in the micro-CT scans. The halysitid coral not only continues from one lithology into the other (Fig. 4A), but broken, tilted pieces fit the missing parts between corallites from the two adjacent limestone beds (Fig. 4B, C).

The coral shows cyclic density banding (Figs 5, 6). The mean distance measured between 111 correlatable minima of density banding is $3.8 \mathrm{~mm}$ (standard deviation $0.9 \mathrm{~mm}$ ) with 94 minima in the lowermost sample (Fig. 5, Tabs 1,2). The distance between density banding minima for the favositid coral is $1.8 \mathrm{~mm}$ (standard deviation $0.4 \mathrm{~mm}$ ).
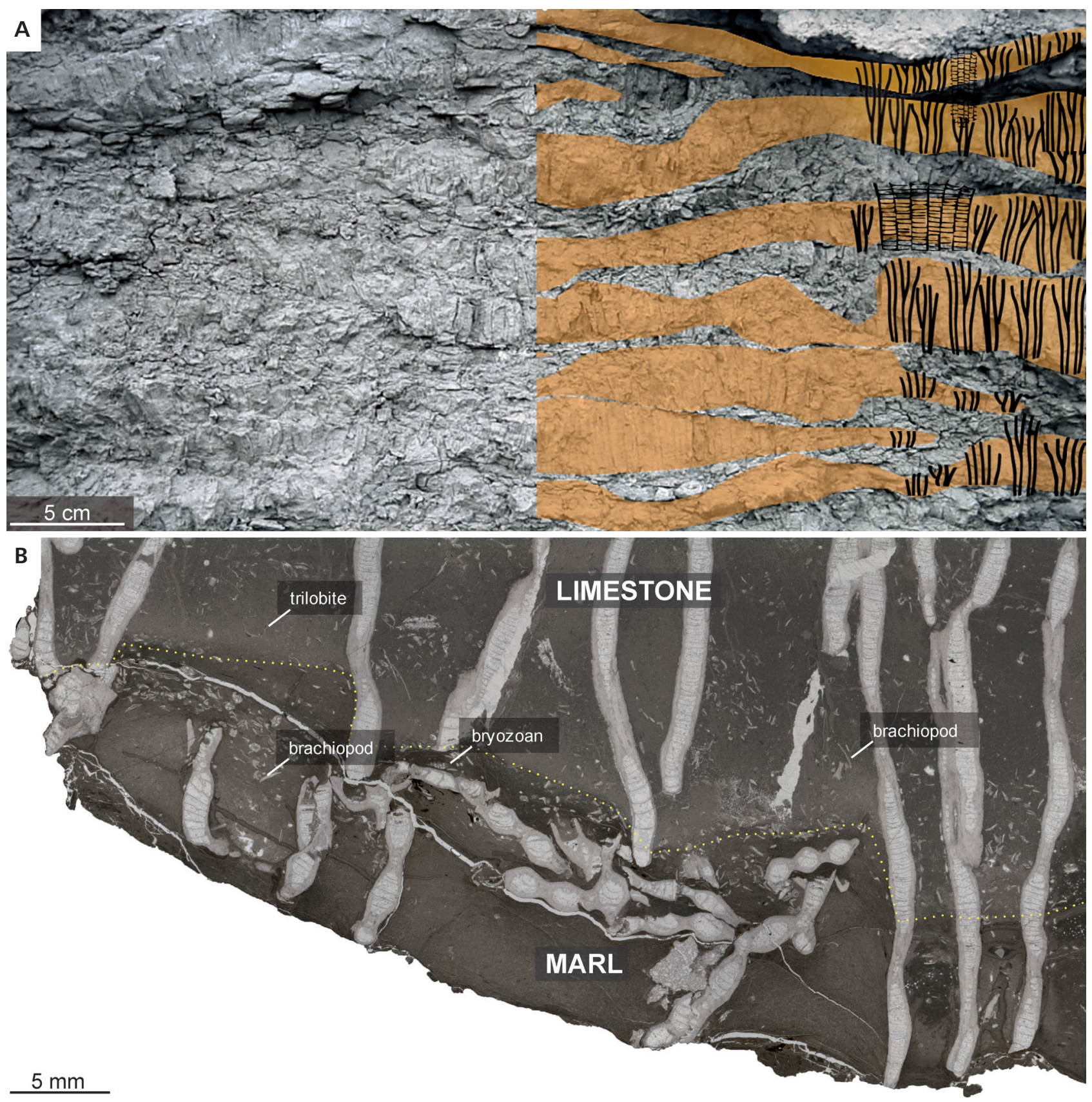

Figure 2. A - close-up view of the outcrop at Ireviken; left side plain photo; right side with colour-coded marl (orange) and exemplary Halysites and favositid corals. $\bullet \mathrm{B}$ - thin section with marl and limestone and small washed-in fragments in Halysites. 

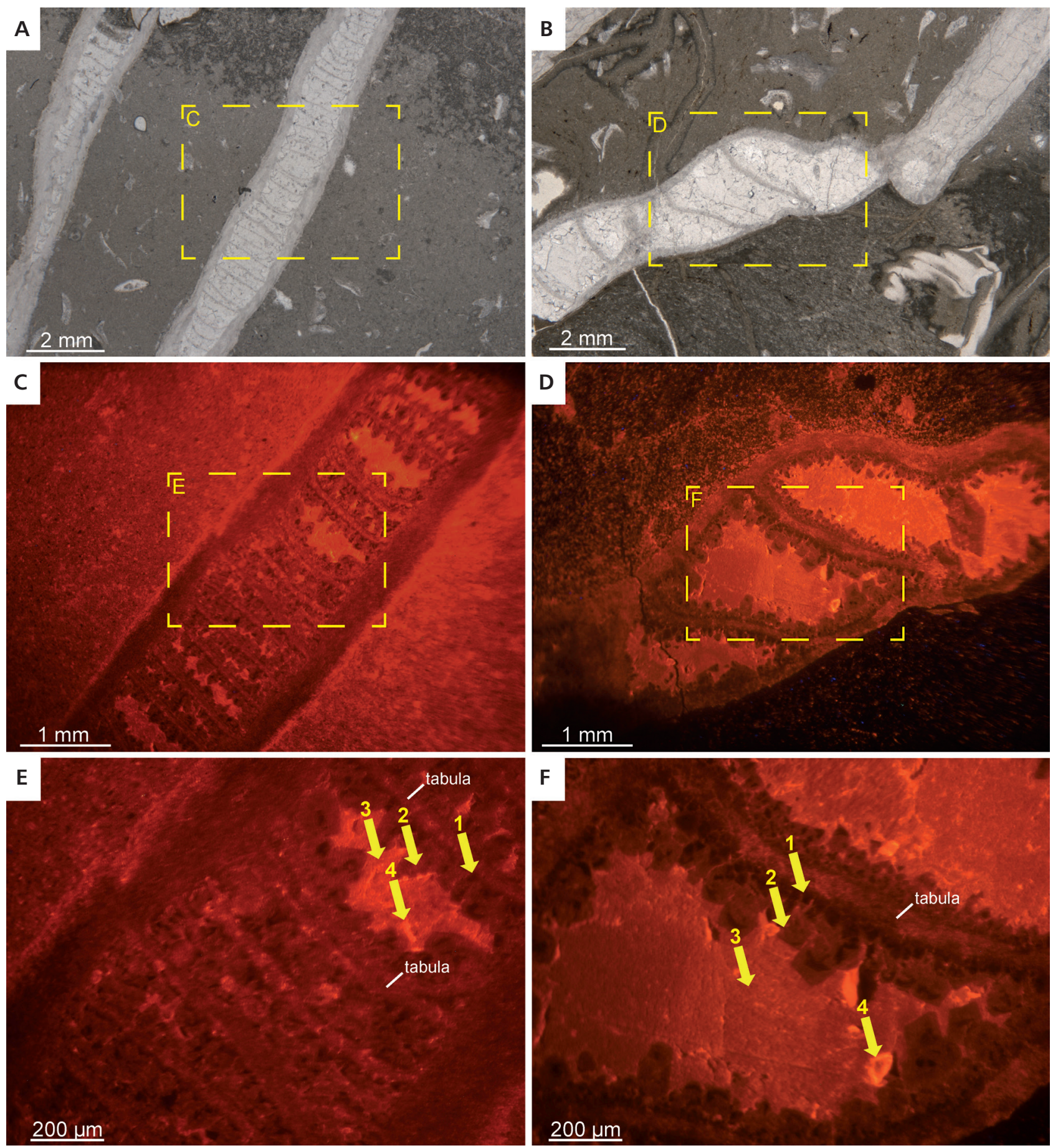

Figure 3. Cathodoluminescence in Halysites. - A, C, E - limestone; A - selected limestone area; C - in limestone; note the luminescent matrix; E - close-up view of limestone; the arrows indicate the four cement generations. $・$ B, D, E - marl; B - selected marl area; D - in marl, note the thin luminescent rim on top of the coral which is only found in close proximity of the unimpaired coral chamber filled with calcite spar; $\mathrm{F}$ - close-up view of marl, the arrows also indicate the four cement generations.

The distance between two minima in Halysites is covered by 13.4 tabulae (standard deviation $2.6 \mathrm{~mm}$ ) on average (Fig. 7). The counts of 19 or more tabulae between two minima probably result from unidentified minima in between.
The corals also show several growth interruptions, either in individual corallites (Fig. 8A) or in adjacent corallites at the same height (Fig. 8B). Some growth interruptions are followed by rejuvenation, sometimes after sediment filling in the tabular chamber in the corallite 

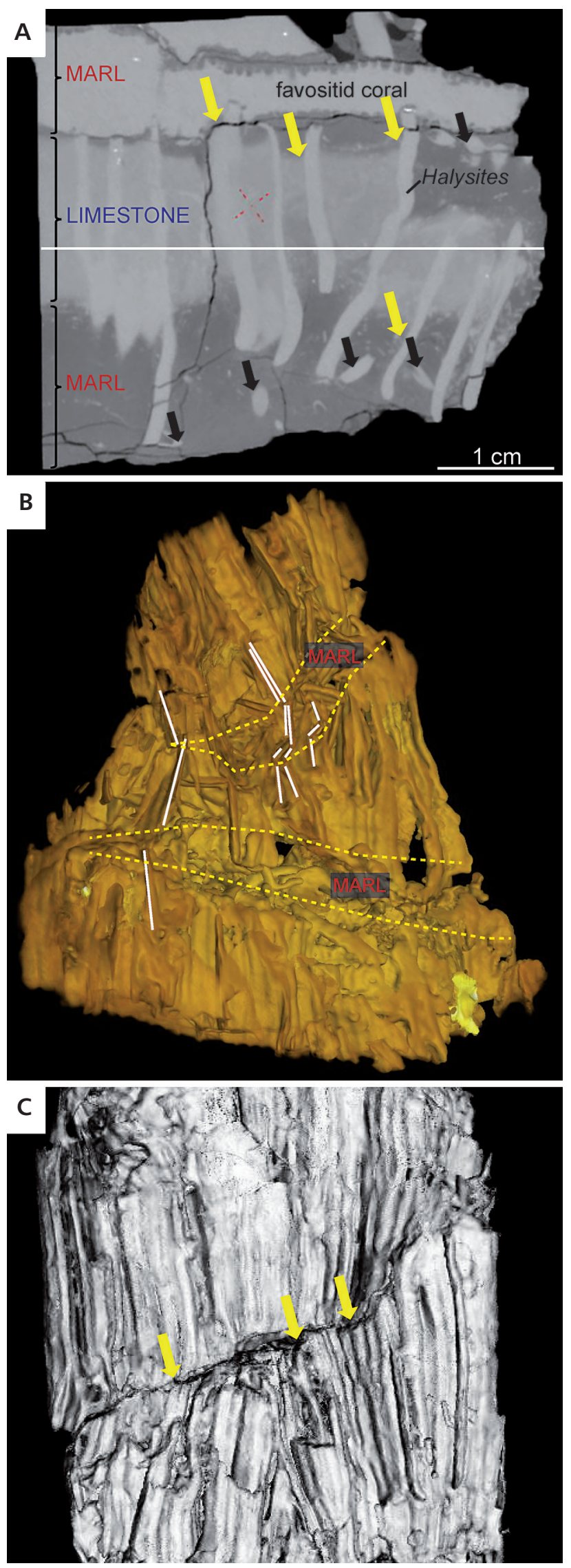

(Fig. 8C), by development of new corallites (Fig. 8B), or by overgrowth by favositid corals (Fig. 8D).

In the lowest part, a layer enriched in sphalerite (Fig. 9A, B) and pyrite was detected (Fig. 9C, D). The corallites are coated both on the outside and on the inside with thinly dispersed pyrite (Fig. 9C, D).

The favositid coral continues from limestone into marl, though the major part of the coral lies within marl (Fig. 10A). The coral displays growth periodicity by density banding (Fig. 6A) and several growth interruptions (Fig. 10B). In the marl, stylolites (Fig. 10C) are found in the coral. Breakage by compaction can be detected at points of growth interruption where broken remains were not removed from the coral (Fig. 10D).

\section{Discussion}

\section{Age of the coral colony}

Following the assumption that density banding represents annual cycles (e.g. Ma 1934, Mazzullo 1971, Scrutton 1998, Bae et al. 2006), the lowermost sample has an age of 34 years, as 34 horizontal lines of correlatable density banding minima were counted (Fig. 11). Dividing the coral colony's height $(144.4 \mathrm{~mm})$ by the mean distance between density banding minima $(3.8 \mathrm{~mm})$ results in an age of 38.0 years (Tab. 1). In the middle and upper samples, correlation is difficult due to the limited number of identified density banding minima (Fig. 6A, B). The age of the colonies can thus only be gauged by measuring their height in the limestone and dividing it by the mean distance between density minima. For the middle sample, an age of 25.4 years was calculated. For the favositid coral a mean annual growth rate of $1.8 \mathrm{~mm}$ was measured, but as the number of correlatable density banding minima was very limited, literature data was used: With a $5 \mathrm{~mm}$ minimum growth rate for favositid corals (Scrutton \& Powell 1980, Scrutton 1998), the age is 15.1 years. The age of the uppermost sample was calculated as 22.7 years. Undervaluing the age of the coral in the compacted marl is minor, as some corallites are unbroken and continue from limestone into the marl. Furthermore, in thin sections and micro-CT scans the size of broken corallites limits the possible undervaluation.

Figure 4. Micro-CT scans. $-A$ - density differences reveal areas of limestone and marl, as well as the two coral colonies (favositid and Halysites). Yellow arrows mark halysitid corallites traversing lithological borders unimpaired. Black arrows show broken corallites in the marl. B - extracted Halysites colony; it is broken in the marl and wellpreserved in the limestone. White lines indicate corallites that were formerly connected. $\cdot \mathrm{C}$ - large scan of the lowest sample from Ireviken; the thin marl layer cuts the colony, though it is clearly visible, the colony once continued. 
Table 1. Sizes, distances between density minima, and the resulting age of the coral colonies from Ireviken. Abbreviation: * - minimum growth rate for favositid corals in Young \& Kershaw (2005).

\begin{tabular}{lccc}
\hline Sample & Size $(\mathrm{mm})$ & $\begin{array}{c}\text { Mean distance be- } \\
\text { tween density minima }\end{array}$ & Age (years) \\
\hline uppermost sample, Halysites & 86.4 & 3.8 & 22.7 \\
middle sample, Halysites & 0.8 & 3.8 & 0.2 \\
middle sample, Halysites & 28.8 & 1.8 & 16.1 \\
middle sample, Halysites & 28.8 & $5.0^{*}$ & 5.8 \\
middle sample, Halysites & 34.7 & 3.8 & 9.1 \\
lowest sample, Halysites & 144.6 & 3.8 & 38.0 \\
\hline
\end{tabular}

Table 2. Distances and number of tabulae between density banding minima for the three samples. Abbreviations: $\mathrm{d}-$ distance ( $\mathrm{mm}$ ); $\mathrm{Nt}-\mathrm{number}$ of tabulae.

\begin{tabular}{|c|c|c|c|c|c|c|c|c|c|}
\hline \multicolumn{8}{|c|}{ lowermost sample } & \multicolumn{2}{|c|}{ middle sample } \\
\hline d & $\mathrm{d}, \mathrm{Nt}$ & d & $\mathrm{d}, \mathrm{Nt}$ & d & $\mathrm{d}, \mathrm{Nt}$ & d & $\mathrm{d}, \mathrm{Nt}$ & d & $\mathrm{d}, \mathrm{Nt}$ \\
\hline 3.37 & 13 & 4.33 & 13 & 2.54 & 11 & 3.38 & 13 & 3.27 & 15 \\
\hline 4.71 & 14 & 4.07 & 12 & 2.31 & 11 & 3.98 & 14 & 3.75 & 14 \\
\hline 3.34 & 10 & 2.99 & 11 & 3.39 & 13 & 3.02 & 11 & 4.15 & 12 \\
\hline 3.58 & 14 & 4.27 & 14 & 3.76 & 15 & 3.70 & 11 & 3.11 & 13 \\
\hline 3.87 & 14 & 3.76 & 14 & 4.61 & 19 & 3.90 & 13 & 5.60 & 17 \\
\hline 2.89 & 10 & 4.38 & 16 & 4.38 & 19 & 3.72 & 12 & 2.93 & 10 \\
\hline 2.75 & 9 & 4.31 & 16 & 3.63 & 13 & 2.99 & 11 & 3.71 & 12 \\
\hline 3.14 & 9 & 8.25 & 14 & 3.48 & 13 & 5.83 & 19 & 1.50 & 8 \\
\hline 3.83 & 14 & 3.36 & 11 & 3.11 & 14 & 5.31 & 21 & 4.04 & 14 \\
\hline 3.74 & 12 & 4.78 & 17 & 3.06 & 15 & 4.01 & 14 & 4.57 & 16 \\
\hline 5.66 & 19 & 4.71 & 16 & 3.03 & 13 & 3.53 & 16 & 4.18 & 13 \\
\hline 5.36 & 19 & 3.57 & 13 & 2.25 & 10 & 4.02 & 16 & \multicolumn{2}{|c|}{ uppermost sample } \\
\hline 3.37 & 12 & 3.23 & 12 & 3.53 & 12 & 3.86 & 15 & d & $\mathrm{d}, \mathrm{Nt}$ \\
\hline 3.03 & 13 & 3.66 & 11 & 3.76 & 14 & 3.74 & 12 & 3.01 & 9 \\
\hline 3.84 & 13 & 4.21 & 12 & 3.32 & 13 & 5.59 & 20 & 2.00 & 7 \\
\hline 4.07 & 15 & 3.76 & 13 & 3.33 & 12 & 2.88 & 11 & 3.05 & 11 \\
\hline 4.09 & 14 & 4.11 & 14 & 3.76 & 12 & 3.85 & 15 & 3.11 & 8 \\
\hline 5.10 & 16 & 4.08 & 13 & 3.41 & 12 & - & - & 4.42 & 17 \\
\hline 4.35 & 12 & 3.71 & 15 & 3.37 & 13 & - & - & 4.32 & 12 \\
\hline
\end{tabular}

Liang et al. (2018) reported an inferred annual growth rate of $6 \mathrm{~mm}$ for Halysites catenularius from the Sheinwoodian of Estonia. With a mean of $3.8 \mathrm{~mm}$, our results are lower but still within the growth rate for Halysites sp. of $3.4 \mathrm{~mm}$ to $11.7 \mathrm{~mm}$ according to Liang et al. (2018). The calculated annual growth rate of $1.8 \mathrm{~mm}$ for the favositid coral is also somewhat lower than the data from the literature, which report an annual growth rate of 5 to $18 \mathrm{~mm}$ (Scrutton \& Powell 1980, Scrutton 1998). As both measured growth rates are lower than the literature growth rates (Liang et al. 2018, Scrutton \& Powell 1980, Scrutton 1998), external factors, like reduced light in this deeper environment or lower nutrient supply, might have caused reduced growth rates in both coral species. Still, in the Halysites specimen, the number of tabulae between density banding minima (mean of 13.4) correspond with the approximately 13 lunar cycles reported for Silurian years (e.g. Scrutton 1965, Mazzullo 1971). This supports the interpretation of variation in density banding as annual cyclicity. Thus, the time recorded in this colony spans only few tens of years.

\section{Time span of the limestones and marls}

The calculated age of less than 100 years for the coral colonies leads to the question of how much time is recorded in the limestone-marl alternation penetrating through 


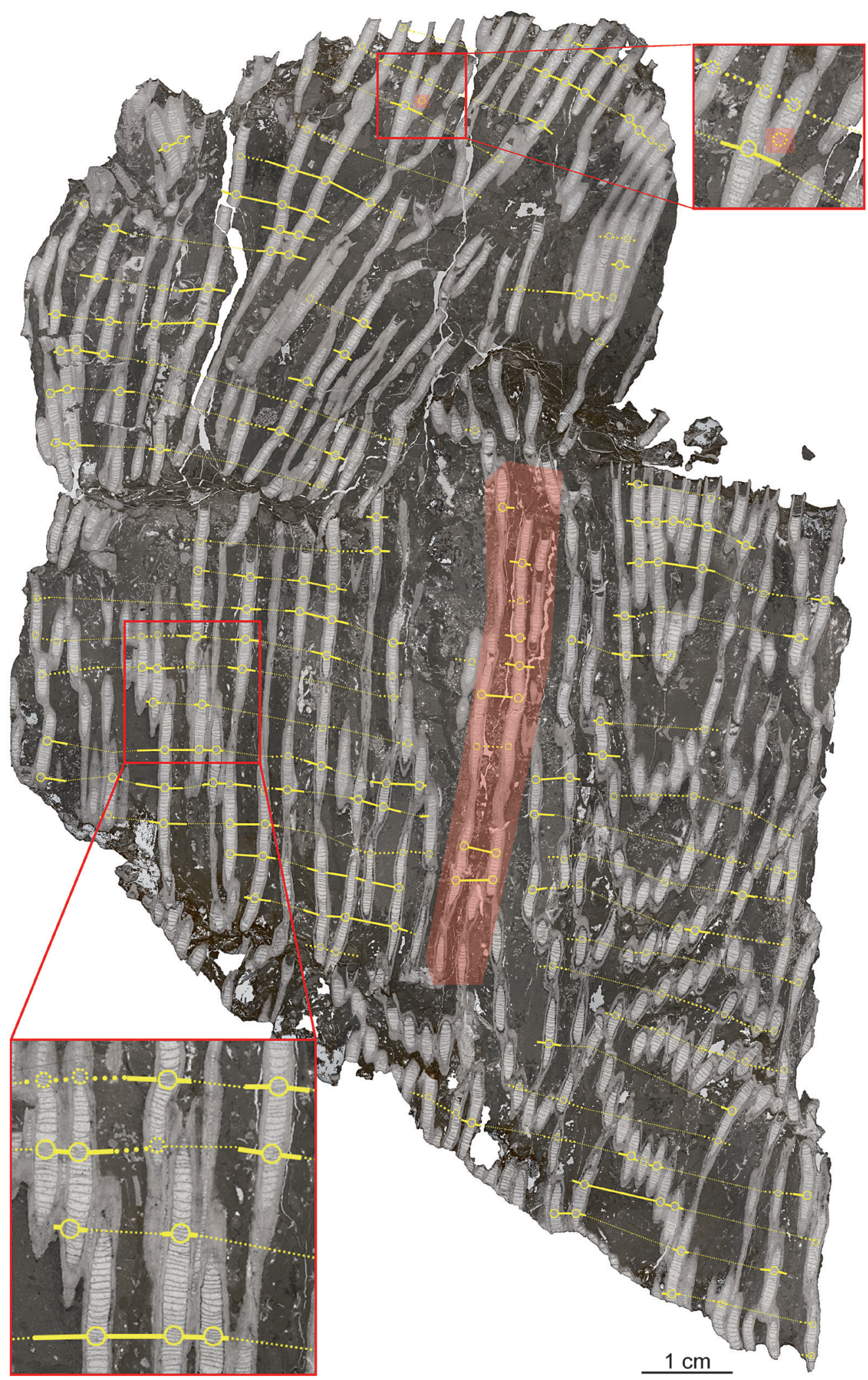

Figure 5. Density banding minima of Halysites in the lowermost Ireviken sample. Legend: yellow circle - density banding minima; dotted yellow circle - uncertain density banding minima; yellow line - connection of density banding minima; dotted yellow line - connecting uncertain density banding minima; thin dotted yellow line - connection across corallites without identified density banding minima. Red background marks minima that could not be correlated with the rest. A total number of 34 lines were correlated. 
A
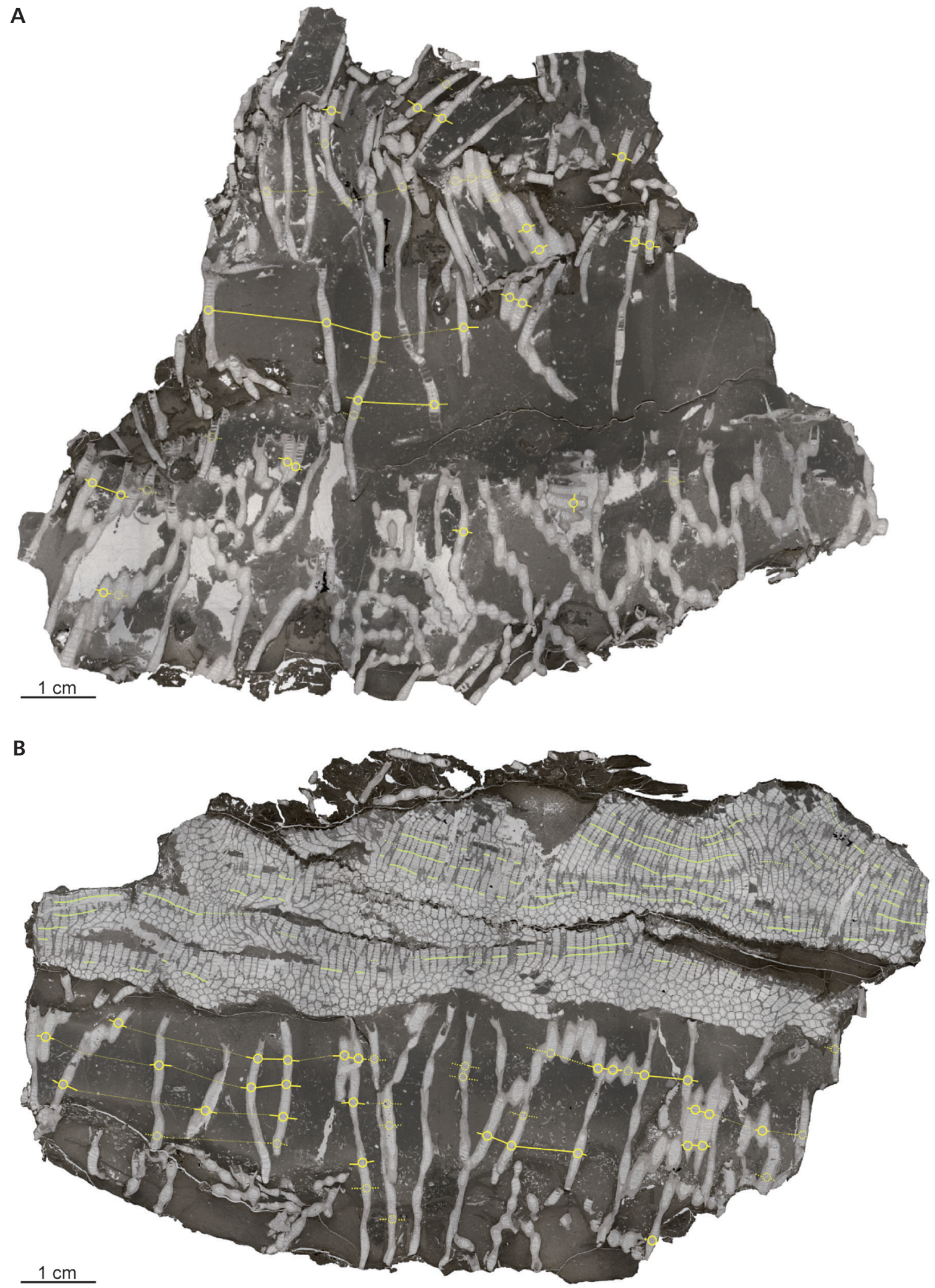

Figure 6. A - density banding minima of Halysites in the uppermost Ireviken sample and B - in the middle Ireviken sample. Legend: yellow circle density banding minima; dotted yellow circle - uncertain density banding minima; yellow line - connection of density banding minima; dotted yellow line - connecting uncertain density banding minima; thin dotted yellow line - connection across corallites without identified density banding minima; green line - density banding minima in the favositid coral. 


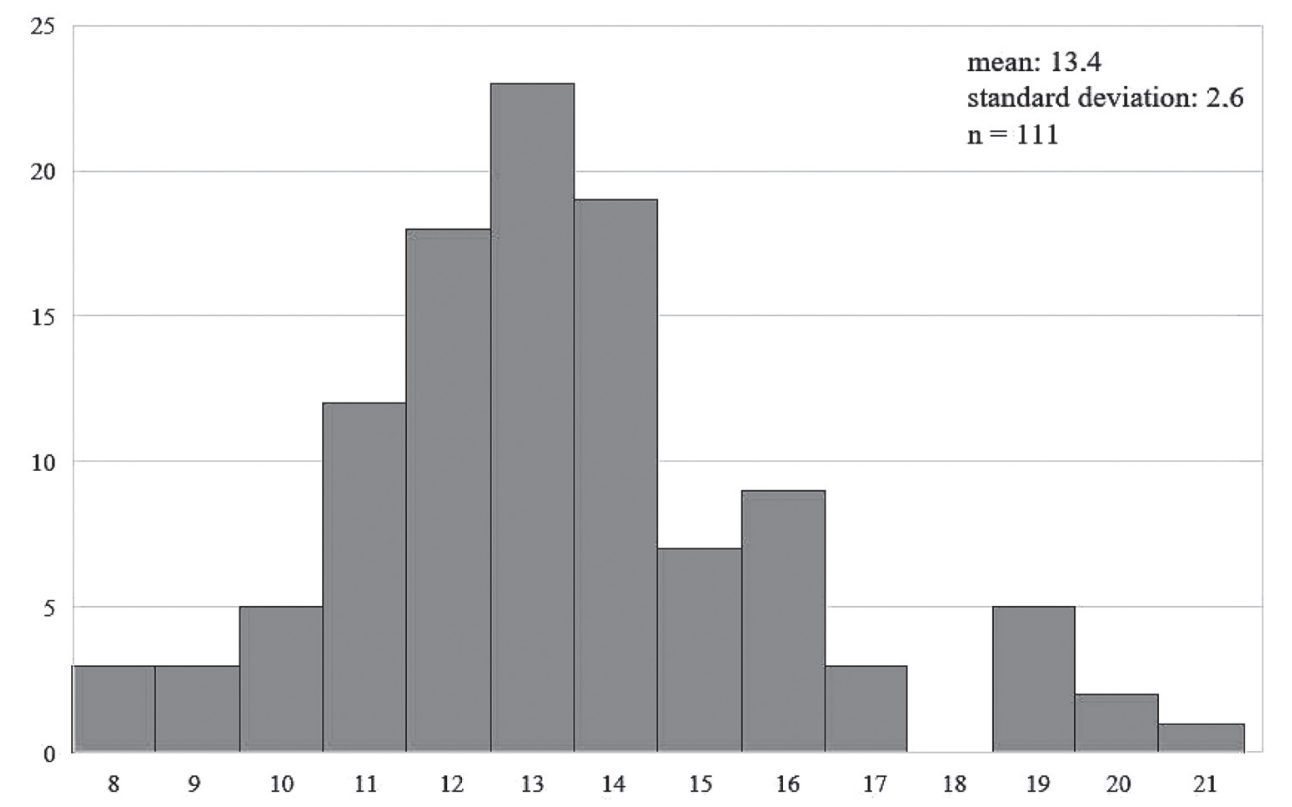

Figure 7. Histogram of the number of tabulae between density banding minima in Halysites from all three samples from Ireviken. The second small peak at 19 is probably related to double distance due to unidentified density banding minima.
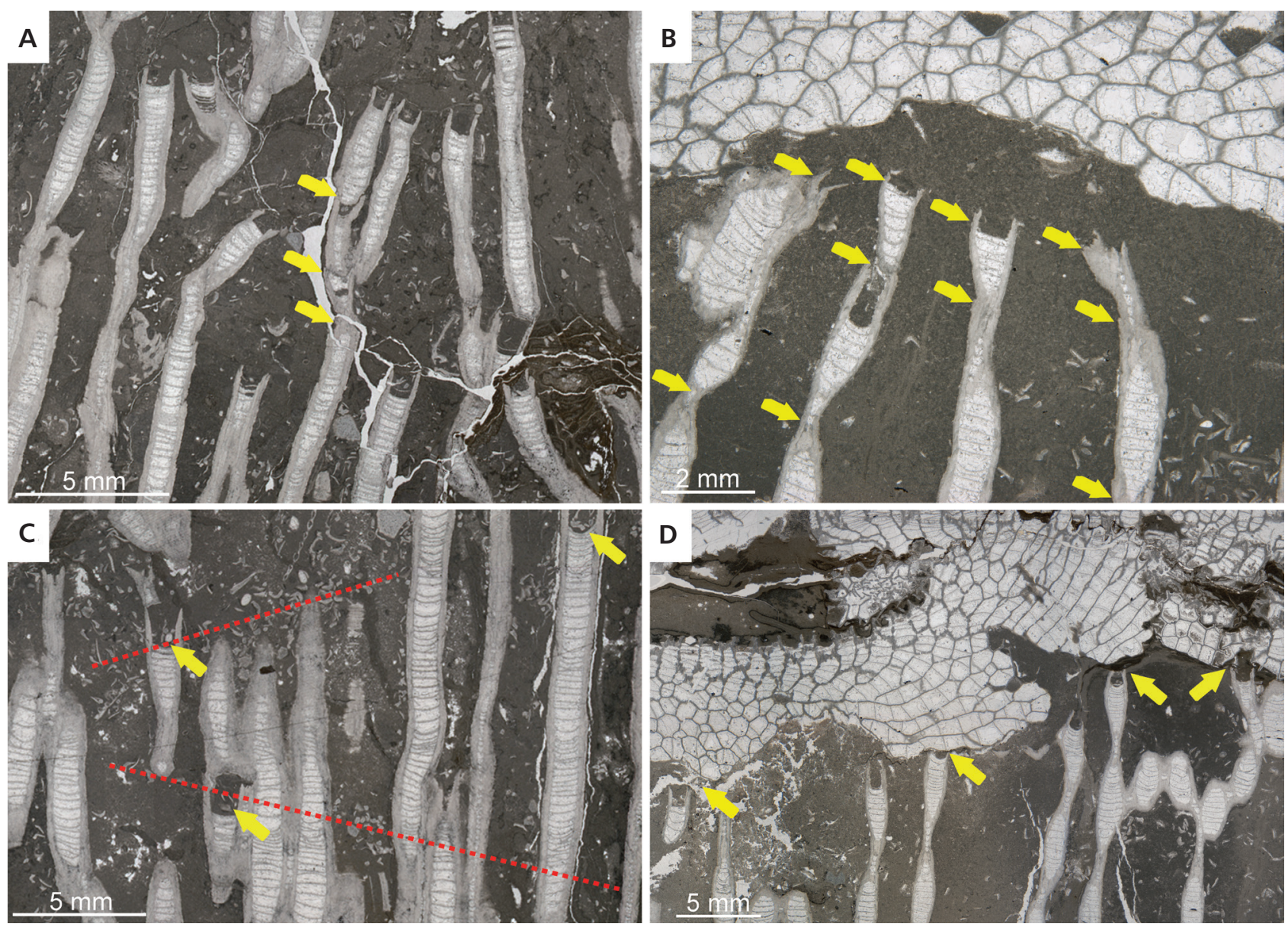

Figure 8. Halysites from Ireviken. • A - several growth interruptions within one corallite are indicated by yellow arrows. $\bullet$ B - contemporaneous growth interruptions in several corallites marked by yellow arrows. $\cdot \mathrm{C}$ - infill of corallite (yellow arrow) with the same sediment (red dashed line) as outside documenting (1) contemporaneous sediment infill and growth of the coral, and (2) different angles between layers with coarser sediment infill. $\bullet$ $\mathrm{D}$ - death of the Halysites (yellow arrows) can be followed by settlement of a favositid coral colony. 
the corals. In high energy reefs, fine-grained sediment is usually constantly removed from the reef or preserved in reef cavities or coral interspaces, which are, however, rare. In these cases, the matrix does not necessarily represent the same time span as the surrounding reefal framework. The example from Ireviken studied here comes from a low energy environment, formed in a calm platform slope setting. This environment is characterised by muddy sediments without indications for enhanced water energy such as waves or currents. In contrast to many other tabulate corals, Halysites is a typical soft-bottom dweller and is therefore quite common in the Lower Visby Formation (Mõtus \& Klaamann 1999). During the life time of the coral, most of the colony was sticking in the sediment, and only a small part was elevated above the seafloor (Buehler 1955, Liang et al. 2016). Presuming that coeval sediment was baffled between the corallites, the time span of the pervasive limestone-marl couplets would be less than 100 years. The calm depositional environment would speak for at least minor sediment removal. But as layers enriched in fossil fragments are not always parallel (Fig. 8C), the filling of the lacunae might have transpired at different rates.

The layerwise enrichment of pyrite within the corallite and the matrix could be seen as an argument for coeval sedimentation and coral growth, as, e.g. temporally higher input of organic material or clay could fuel pyrite or sphalerite growth (Fig. 9). The formation of sphalerite is unknown so far, but a common feature in the Lower Visby Formation (Spjeldnaes 2002). On the other hand, there is no response of the coral's growth rate, the number of tabulae, or an increase in growth interruptions, which could be expected as corals are sensitive to changes in the depositional environment (Young \& Kershaw 2005). Thus, this enrichment might rather be the product of precipitation in dysoxic or anoxic shallow burial conditions.

Accepting only minor removal of sediment from the coral's interstices in this low energy environment
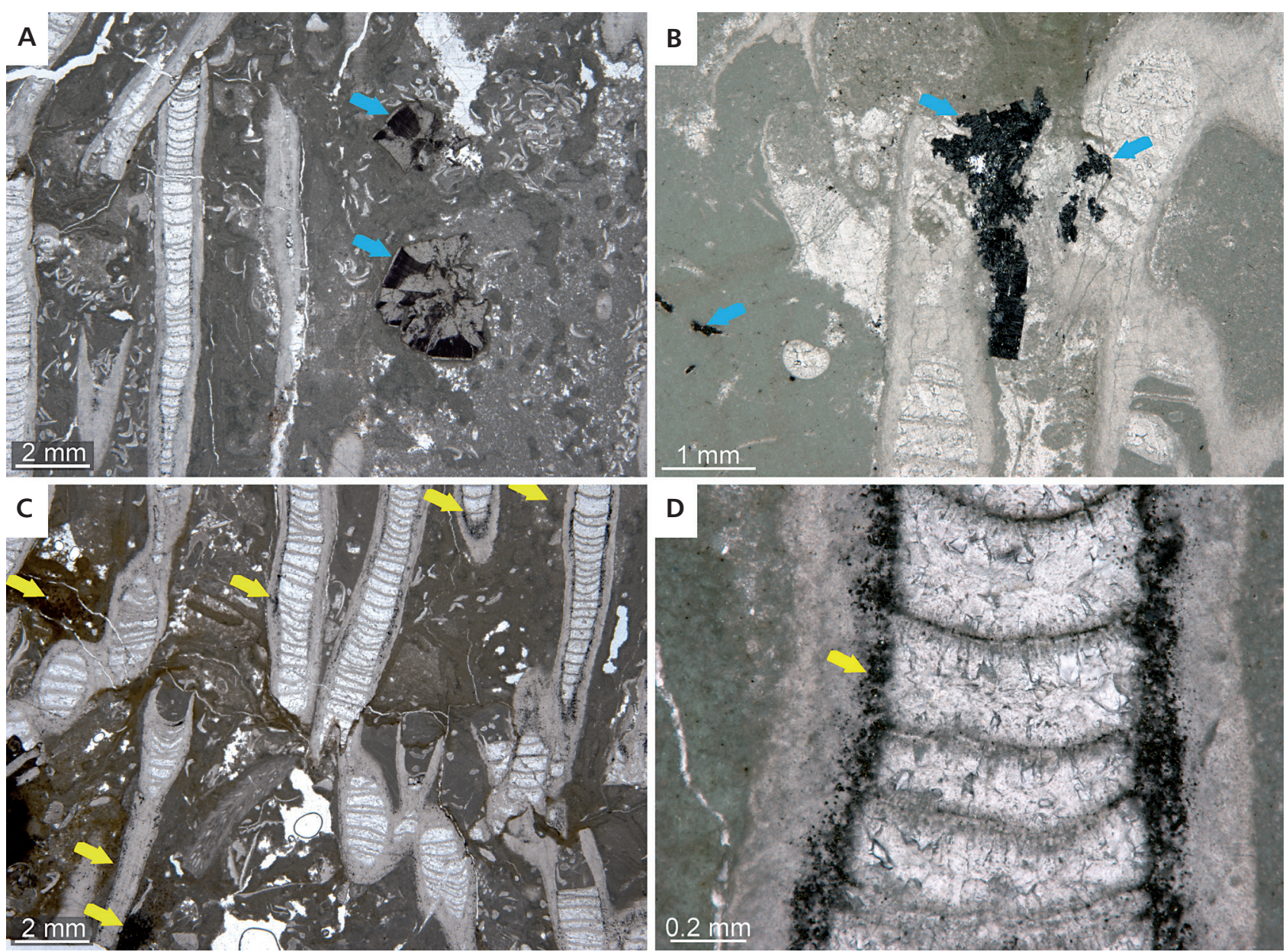

Figure 9. Sphalerite and pyrite in the Ireviken samples. • A - sphalerite (blue arrow) in the lowest sample. Corallites next to it show dark rims of pyrite like in $\mathrm{C}$ and D. $\bullet \mathrm{B}$ - sphalerite in the uppermost sample also within a corallite. Picture is compiled of transmitted light and reflected light microscopy. $\bullet$ $\mathrm{C}$ - pyrite (yellow arrows) within corallites and matrix from the lowest sample. $\bullet \mathrm{D}$ - close-up view of a corallite with pyrite (yellow arrow). 

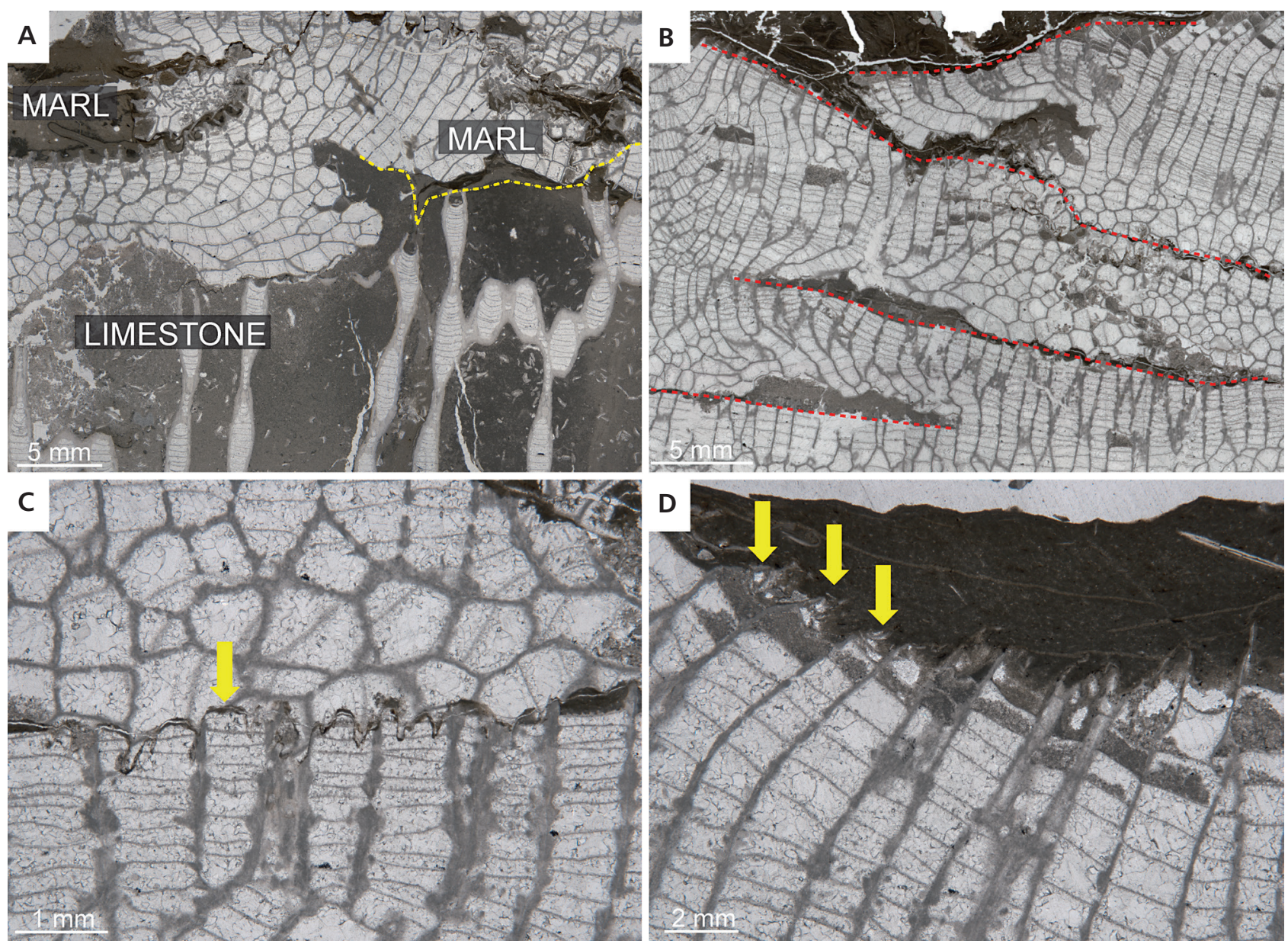

Figure 10. Favositid coral from the middle sample from Ireviken. $\bullet \mathrm{A}$ - showing the coral started growing in the limestone and continues into the marl. $\bullet \mathrm{B}-$ several growth interruptions are indicated by the red dashed line. $\bullet \mathrm{C}-$ a stylolite (yellow arrow). $\bullet \mathrm{D}-$ small breakage of the corallites' top (yellow arrow) mark signs of compaction within the favositid coral in the marl which is otherwise too solid to break, like Halysites. Note that the broken pieces in $\mathrm{D}$ were not removed.

gives a sedimentation rate of $3.4 \mathrm{~m} / \mathrm{k} . \mathrm{y}$. within the coral colony. This is about ten times the commonly assumed sedimentation rate for slope sediments below the storm wave base (e.g. compilation in Read et al. 1991, Tucker et al. 2009). Wright (1994) pointed out that Carboniferous depositional systems might differ in productivity from comparative Cenozoic models. Adopting the sedimentation rate from the Halysites colonies to the surrounding limestone-marl alternation, which shows the same bed thickness inside and outside the biostrome, the deposits of the whole Lower Visby Formation with its exposed thickness of about $12 \mathrm{~m}$ can be extrapolated to only 3.5 thousand years, which seems highly unrealistic. Furthermore, work by Sadler (e.g. 1981, 1994) and Schlager (e.g. 2005) showed the dependence of sedimentation rate on the length of the observed interval. Regarding these findings and our results, we conclude high sedimentation rates on Silurian platform slopes are possible but must be compensated by phases of non-deposition or at least much lower sedimentation rates (compare van Andel 1981).

\section{Diagenetic influence}

The general assumption for reefal structures is that cementation occurs in parallel with the growth of reef builders before dissolution which is associated with burial and compaction (Wood 1999). This assumption might not be true for the example shown in this study, which is a special type of reefal buildup. Also, the interpretation of marl interbeds reflecting times of higher terrigenous input (Desrochers et al. 2010) is questioned. The results show that the corals once extended from the precursor limestone to the precursor marl sediment without changes in coral growth. The very localised and abrupt compaction can only be explained by a strong mass loss (volume reduction) in the marl and very early cementation in the limestone. Such a scenario is proposed by the model of differential diagenesis by Munnecke \& Samtleben (1996), in which an early diagenetic mass loss is ascribed to aragonite dissolution. According to the model, aragonite dissolution took place in distinct 

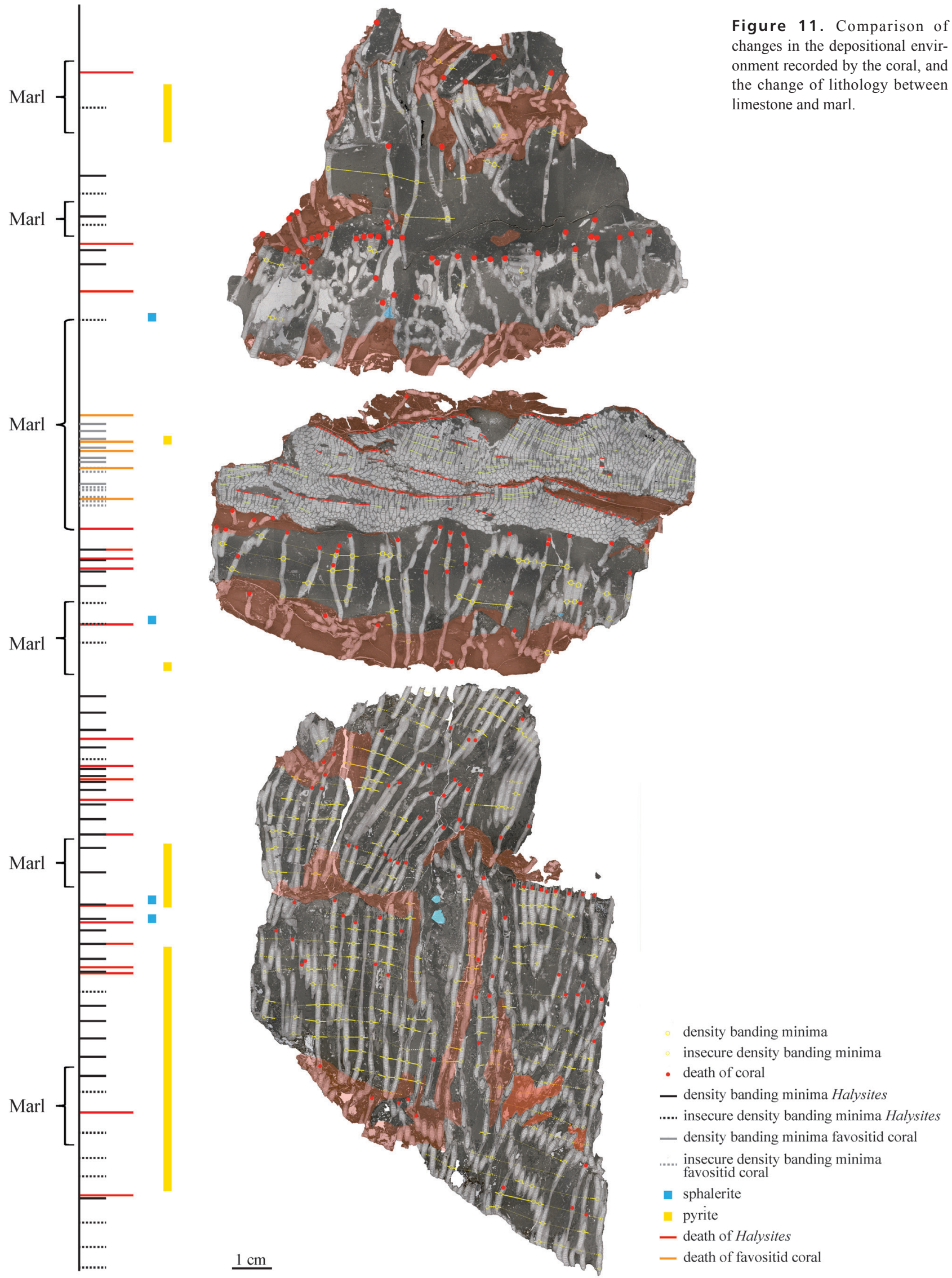
layers in shallow burial depth (more or less parallel to the former seafloor), and the dissolved aragonite reprecipitated as calcite in the adjacent limestone layers. Due to the lack of cementation in the dissolution zone (the later marl), these sediments are later mechanically compacted by ongoing sedimentation to a condensed layer with lower calcium carbonate content. Direct evidence for such a process was provided by Nohl et al. (2019), who demonstrated that primary aragonitic components were selectively removed from the marl and replaced by calcite cement in the limestones. However, in the examples studied here which are from comparatively deep environments, no primary aragonitic fossils are observed in contrast to abundant small fragments of calcitic fossils like trilobites or brachiopods, indicating that most of the dissolved aragonite was mud-sized, probably resulting from shedding from nearby shallow-water platforms. The pitted microspar (Fig. 12), which probably formed as calcite crystals that grew poikilotopically around later dissolved aragonite needles (Munnecke et al. 1997), points to differential diagenesis fuelled by aragonite mud. A contribution of larger aragonitic components from marl, where they are dissolved, is ruled out as the selective deposition of aragonitic fossils in the later marl layer would require a change in the depositional system which is not recorded by the coral. The cement import into the limestones and lack of cementation in the marl is also reflected in their cathodoluminescence behaviour, with bright luminescence in the limestone matrix (Fig. 3C) and its absence in the marl (Fig. 3D). Breakage of the top part of the favositid corallites and the non-removal of the tiny fragments further confirms compaction (Fig. 10D).

In conclusion, the lithological separation into limestone and marl is a diagenetic feature, and the marl does

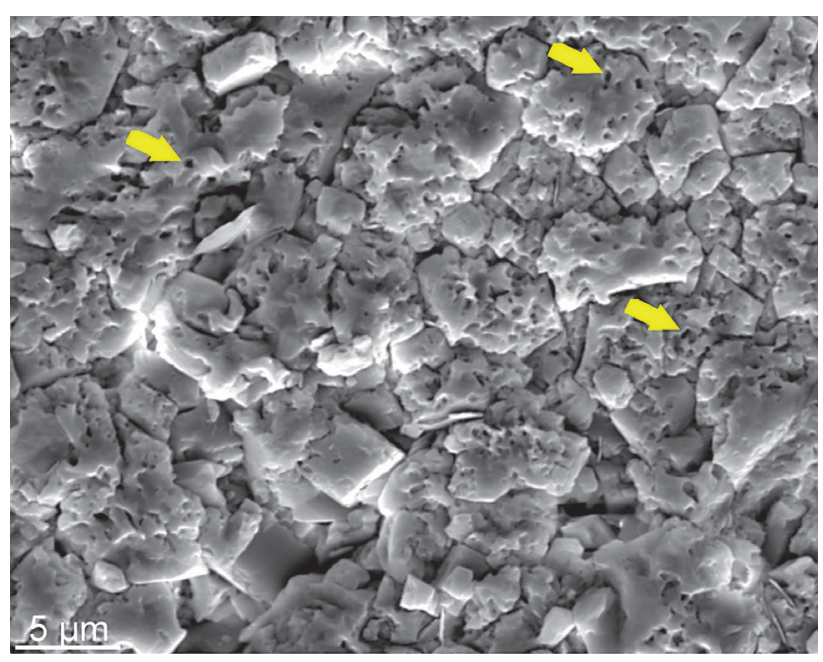

Figure 12. SEM picture of pitted microspar (yellow arrow) indicating the former presence of aragonite needles in the soft precursor sediment. not necessarily represent periods with higher terrigenous input.

The selective compaction also influences the preservation potential of the fossils. More fragile components, like the Halysites compared to the favositid coral, can easily be misinterpreted in terms of correct size and abundance due to the artificial interruptions caused by selective compaction. The components potential for preservation is biased by differential diagenesis, and not by skeletal properties and erosion (Wood 1999). Not only destruction by selective compaction within one specimen, but also the possible selective removal of aragonitic components (Kerans et al. 1986, Munnecke \& Samtleben 1996, Sanders 2004, Cherns et al. 2011) as well as the condensation of calcitic components in the marl (Nohl et al. 2019) might bias acquired abundances and diversity of the fossil assemblage.

During a field trip to Point Laframboise (Anticosti, Canada), a second example of halysitid corals was found, showing the same phenomena as the ones from Gotland. As sampling was not permitted, the section was carefully documented in the field. The section of the Laframboise Member of the Hirnantian Ellis Bay Formation (uppermost Ordovician) comprise up to two metres high biohermal structures (Fig. 13A) that consist mainly of halysitid and other tabulate corals, rugose corals, calcimicrobes and microbialites, stromatoporoids, and bryozoans. Less abundant are fragments of brachiopods and trilobites, as well as crinoid fragments (Long \& Copper 1987). The sediments formed below the fair-weather wave base. Large corals can be found therein, most of them in situ and only a small proportion tilted. The deposits can be divided into microbial and coral-dominated units, reflecting changes in nutrient supply and sunlight (Desrochers et al. 2010). They also include thin argillaceous interbeds. Microbialites and halysitid corals can be found in both lithologies, limestone and marl, but the halysitid coral is selectively broken and compacted in the marl interbed (Fig. 13B, C), like the one from Gotland. In the limestone, the coral is well preserved, though in some cases tilted.

In the example from Gotland, in addition to early differential diagenesis, a late diagenetic influence is observed. Calcite spar within the corallites is here mainly not a phenomenon of early burial. Cathodoluminescence analysis reveals thin dark cements, which probably represent growth-concurrent cements as indicated by Wood (1999), and different generations of luminescent cements in unimpaired coral chambers, both in limestone and marl. These luminescent cement generations are interpreted as late diagenetic, because they are similar in corals from both lithologies. In addition, the accompanying slight luminescent rim of some chambers in the marl and its absence in the rest of the marl supports a late diagenetic origin (Fig. 3D). 

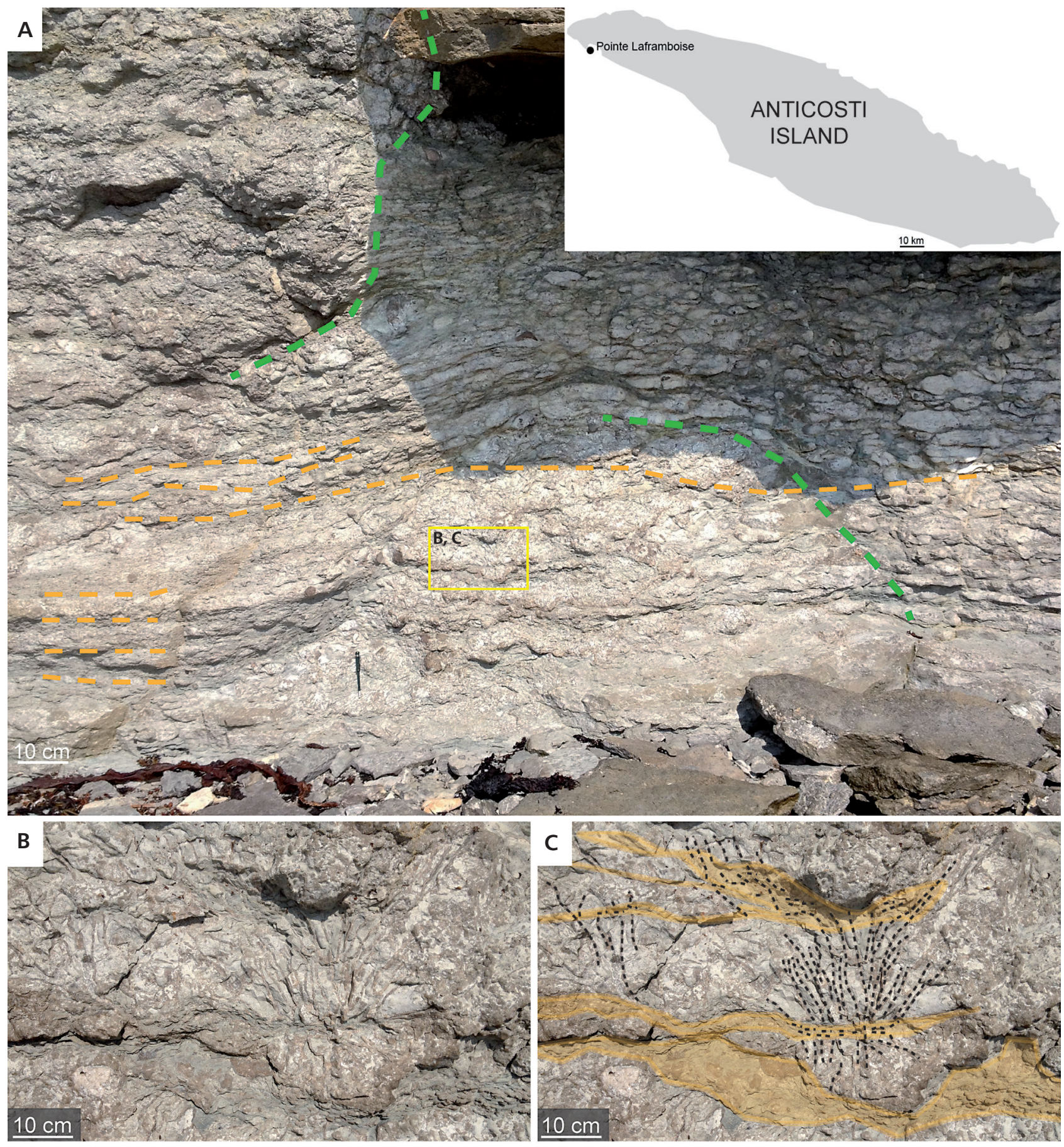

Figure 13. A - outcrop picture of the bioherms of the Ellis Bay Formation at Point Laframboise (Anticosti). $\bullet \mathrm{B}, \mathrm{C}-$ close-up view of Halysites from the Ellis-Bay Formation on Anticosti; B - plain photo; C - marl indicated by yellow colour, the corallites of the Halysites are traced by a black dashed line. Note the deformed and broken Halysites in the marl, and the rare corallites which continue through the lithological boundary.

The favositid coral reveals another proof for a late diagenetic overprint. Several stylolites within the coral (Fig. 10C) show its response to sedimentary overburden in the marl. By losing the aragonitic part of the bolstering matrix during early diagenesis and the resulting mass/ volume loss, the favositid coral is further exposed to localised unbuffered pressure by progressive sedimentary overburden. It develops stylolites as it cannot break like the more fragile Halysites (Figs 10C, 11). Breakage of the top part of the favositid corallites and the nonremoval of the tiny fragments (Fig. 10D) further confirms compaction. 
A

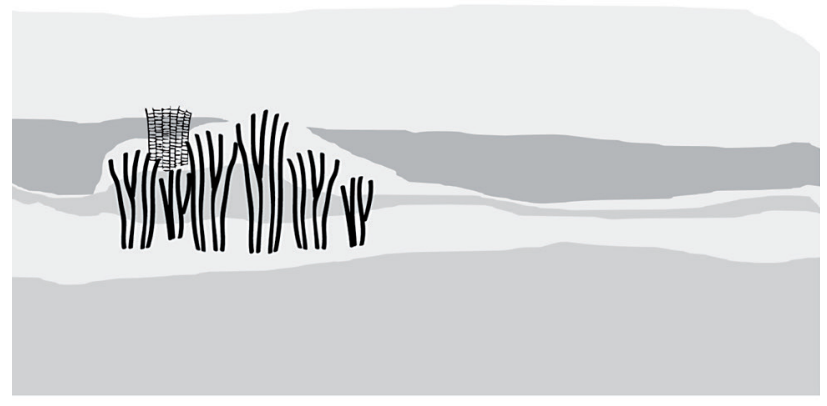

B $\mathrm{CaCO}_{3}$ recipient

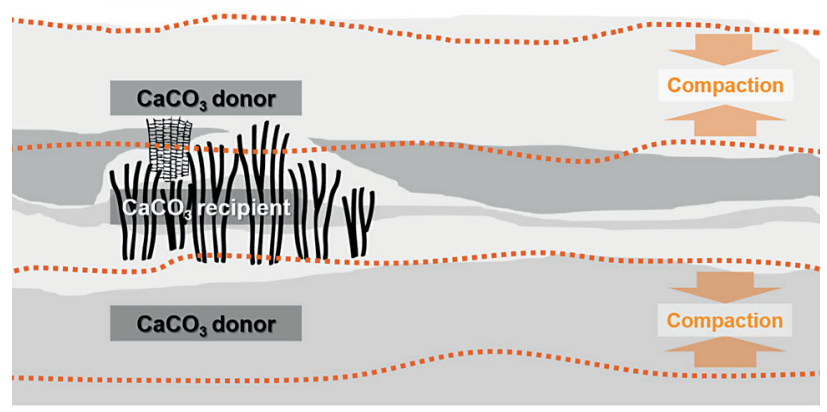

C

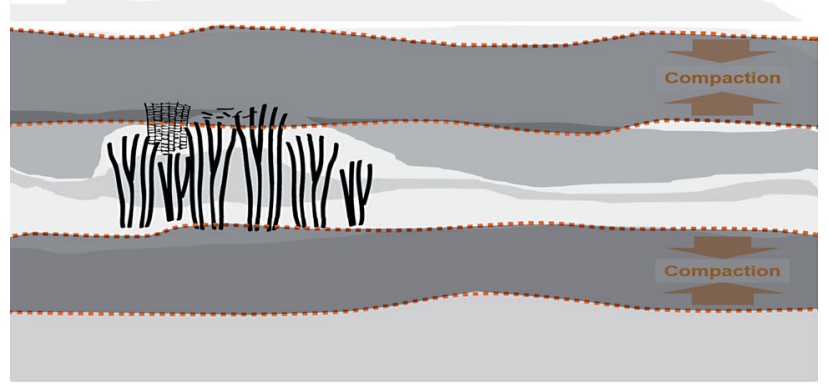

D

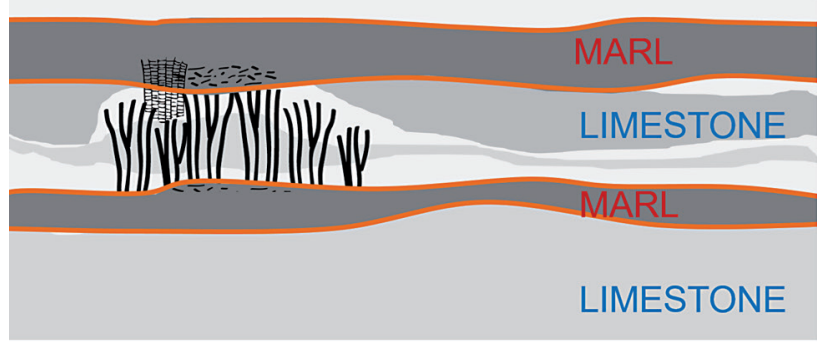

E

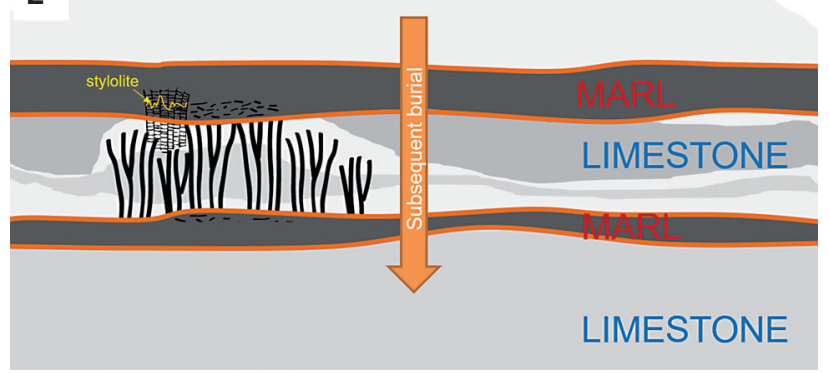

\section{Correlation of changes in the depositional environment with lithological changes}

As shown above, the differentiation of the precursor sediment into limestone and marl occurred early by differential diagenesis. But does this mean that environmental changes are irrelevant for differential diagenesis? Or, in other words, how well are changes in the depositional environment, which are recorded in the coral skeletons, displayed by a change in lithology?

Changes in density banding and growth interruptions in the corals are clear evidence for multiple changes in the depositional environment. The rhythmical change in lithology, however, does not correspond to the corals' growth development (Fig. 11). Some of the growth interruptions are within the limestone, others in the marl. Some crises in skeletal growth are not accompanied by a change in lithology, while the coral colony remains intact through several of these lithological transitions. The best example is the favositid coral, which started growing in the limestone. It displays several severe changes apart from density banding, like interruption and recovery, within the marl, where it eventually died. Between its death and its overgrowth by Halysites the environmental conditions must have changed, but the marl matrix remains unchanged. All these changes in coral growth might be overlooked as they are recorded in the marl. They might be misinterpreted as one event with seemingly more terrigenous input, and a lot of information gets disguised when the diagenetic origin of the marl remains undetected. Figure 14 illustrates the combined sedimentological and diagenetic processes that eventuate in our examples.

With the evidence so far, lithification seems to be indifferent to primary differences in the sedimentary input. The question arises if a single bed necessarily records a specific sedimentary event or if it might crosscut different layers, i.e. merging diachronous sediments into a single

Figure 14. interpreted diagenetic history of the Ireviken biostrome. • A - growth of favositid corals and Halysites; slight changes in the sedimentary input might or might not cause a reaction in terms of growth interruptions or death of the colony. $-\mathrm{B}$ - aragonite mud is dissolved in some areas and precipitated in others in an autocyclic process (compare l'Heureux 2018). • C - the zones losing aragonite are further on less resistant to compaction because of the mass loss. $\cdot \mathrm{D}-$ the mature limestone-marl alternation does not reflect primarily sedimentary differences. Halysites is compacted and broken in the marl. • E - with further sedimentary overburden the differences in carbonate content in limestone and marl are enhanced. The favositid coral develops stylolites. Note the variance in time span within single beds. Within one single limestone bed, the time span might vary depending whether the spot of observation is within or outside of the sediment-baffling Halysites. Topography (e.g. caused by erosion) might cause similar mismatches in the time span. 


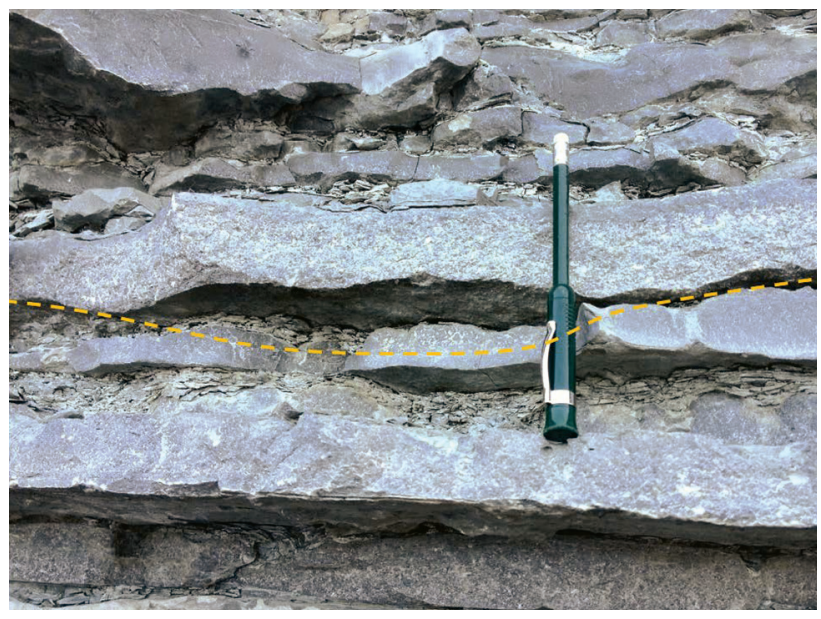

Figure 15. Becsci Formation at Fox-Point, Anticosti. A primary topographic relief is filled with coarse grained sediments, but diagenesis produces horizontal limestone and marl beds indifferent to primary differences.

limestone (or marl) layer. It is reasonable to assume that sedimentation surrounding the sediment baffling Halysites (Liang et al. 2016) was slower than inside the colonies, but the limestone bed crosscutting the coral shows about the same thickness as in the surrounding deposits (compare Figs 1,2A). Accepting a higher sedimentation rate within the coral than outside, the bed embracing the coral covers varying sedimentary events and thus varying time spans depending on the spot of observation (Fig. 14). Besides the reefal structures shown above, the Becscie Formation on Anticosti also reveals other evidence of obliquity between sedimentary layering and diagenetic cementation and, thus, an inconsistent time span within one bed (Fig. 15). Here, a single storm deposit with an erosional base was transformed into two cemented layers (limestone beds), separated by an uncemented layer (marl). And, on the contrary, two primarily very different layers are now part of one and the same limestone layer. Thus, not only the absolute time span recorded within one bed varies, but also the age might be diachronous, depending on the location. The irregular sedimentation and its conversion into more or less regular limestone-marl couplets demand a diagenetic model for the cementation of the beds. The model of differential diagenesis provides such a possibility. A common critique at this point is that these examples are isolated cases. As an increasing number of examples shows either a mismatch of lithology and change in the depositional environment or no change at all, the question has to be raised if we are facing a reporting bias as proposed by Puetz et al. (2016)? The indifferent lithification shown here and for different depositional settings, e.g. in Westphal et al. (2015) and Nohl et al. (2019), put into question the uncritical application of lithological changes in limestone-marl alternations for cyclostratigraphic analyses.

\section{Conclusions}

1) The time-framework of the Halysites and the favositid coral, recorded by annual density banding minima, provide a temporal framework also for the surrounding limestone-marl alternation, even though limited.

2) The reconstructed high sedimentation rate of $3.5 \mathrm{~m} / \mathrm{k} . \mathrm{y}$. for a short observation interval of slope deposits is in line with the Sadler-effect. But the results imply that the missing time in the depositional record is rather reflected by hiatuses than condensed sedimentary cycles.

3) Changes in the depositional environment and primarily sedimentary structures are not necessarily reflected by lithification, i.e. by the lithological changes of limestones and marls. The driving mechanism for the bedding of limestones and marls in the studied reefal structures is differential diagenesis and obviously not a change in sedimentary input.

4) Aragonite mud can serve as a source for the calcium carbonate redistribution of differential diagenesis, making the presence of aragonitic fossils superfluous.

5) Differential diagenesis can distort or disguise primary environmental signals even within reefal structures and can cause a strong preservation bias.

6) The time span recorded in a single bed can be inconsistent depending on the spot of observation, putting into question the uncritical application of lithological changes in limestone-marl alternations for cyclostratigraphic analysis.

7) The results show the importance for cyclostratigraphic studies to examine the complete range of lithologies in a limestone-marl alternation in detail, especially because marls are often avoided for thin section analyses for practical reasons. Otherwise real sedimentological changes might be overlooked because they fade compared to the obvious changes between lithologies, which are, however, partly or even completely diagenetic in origin.

\section{Acknowledgement}

We would like to thank Emilia Jarochowska for sampling, André Desrochers for helpful discussion during the field trip to Anticosti, Birgit Leipner-Mata for thin-section preparation, Michael Joachimski, Agnese Bonomo and Irene Cornacchia for help with the cathodoluminescence analysis, as well as Christian Schulbert and Meike Janßen for micro-CT scans, and the "Bavarian Equal Opportunities Sponsorship - Realisierung von Chancengleichheit von Frauen in Forschung und Lehre (FFL) - Realization of 
Equal Opportunities for Women in Research and Teaching" for financial support. Furthermore, we would like to thank the editor Carlton Brett, as well as Lesley Cherns and an anonymous second reviewer for their constructive criticism and suggestions.

\section{References}

Adomat, F., Munnecke, A. \& Kido, E. 2016. Mass occurrence of the large solitary rugose coral Phaulactis angusta at the boundary Lower/Upper Visby Formation in the Silurian of Gotland, Sweden: palaeoecology and depositional implications. GFF 138(3), 393-409. DOI 10.1080/11035897.2015.1103780

Bádenas, B., Aurell, M., Armendáriz, M., Rosales, I., García-Ramos, J.C. \& Piñuela, L. 2012. Sedimentary and chemostratigraphic record of climatic cycles in Lower Pliensbachian marl-limestone platform successions of Asturias (North Spain). Sedimentary Geology 281, 119-138.

DOI 10.1016/j.sedgeo.2012.08.010

BAE, B.-Y., LeE, D.-J. \& Elias, R.J. 2006. Life-history strategies of a species of Catenipora (Tabulata; Upper Ordovician; southern Manitoba, Canada). Lethaia 39(2), 141-156. DOI 10.1080/00241160600623723

Berkowski, B. \& Zapalski, M.K. 2018. Large dwellers of the Silurian Halysites biostrome: rhizosessile life strategies of cystiphyllid rugose corals from the Llandovery of Gotland. Lethaia 51(4), 581-595. DOI 10.1111/let.12279

Böhm, F., Westrhal, H. \& Bornholdt, S. 2003. Required but disguised: environmental signals in limestone-marl alternations. Palaeogeography, Palaeoclimatology, Palaeoecology 189, 161-178. DOI 10.1016/S0031-0182(02)00639-9

Buehler, E.J. 1955. The morphology and taxonomy of the Halysitidae. Peabody Museum of Natural History, Bulletin 8, 1-79.

Calner, M., Sandström, O. \& Mõtus, M.-A. 2000. Significance of a Halysitid-Heliolitid Mud-Facies Autobiostrome from the Middle Silurian of Gotland, Sweden. Palaios 15(6), 511-523. DOI 10.1669/0883-1351(2000)015<0511:SOAHHM >2.0.CO;2

Cherns, L., Wheeley, J.R. \& Wright, V.P. 2011. Taphonomic Bias in Shelly Faunas Through Time: Early Aragonitic Dissolution and Its Implications for the Fossil Record, 79-105. In Allison, P.A. \& Bottuer, D.J. (eds) Taphonomy: Process and Bias Through Time. Springer Netherlands, Dordrecht. DOI 10.1007/978-90-481-8643-3_3

Cruz-Piñón, G., Carricart-Ganivet, J.P. \& Espinoza-Avalos, J. 2003. Monthly skeletal extension rates of the hermatypic corals Montastraea annularis and Montastraea faveolata: biological and environmental controls. Marine Biology 143(3), 491-500. DOI 10.1007/s00227-003-1127-3

Da Silva, A.C., De Vleeschouwer, D., Boulvain, F., Claeys, P., Fagel, N., Humblet, M., Mabille, C., Michel, J., Sardar Abadi, M., Pas, D. \& Dekkers, M.J. 2013. Magnetic susceptibility as a high-resolution correlation tool and as a climatic proxy in Paleozoic rocks - Merits and pitfalls: Examples from the Devonian in Belgium. Marine and Petroleum Geology 46, 173-189.

DOI 10.1016/j.marpetgeo.2013.06.012
Desrochers, A., Farley, C., Achab, A., Asselin, E. \& Riva, J.F. 2010. A far-field record of the end Ordovician glaciation: The Ellis Bay Formation, Anticosti Island, Eastern Canada. Palaeogeography, Palaeoclimatology, Palaeoecology 296(3), 248-263. DOI 10.1016/j.palaeo.2010.02.017

Gygi, R.A. 2012. Quantitative Geology of Late Jurassic Epicontinental Sediments in the Jura Mountains of Switzerland. 216 pp. Birkhäuser Basel, Basel.

DOI 10.1007/978-3-0348-0136-2

Hallam, A. 1986. Origin of minor limestone-shale cycles: climatically induced or diagenetic? Geology 14, 609-612. DOI 10.1130/0091-7613(1986)14<609:OOMLCC >2.0.CO;2

Hede, J.E., 1921. Gottlands Silurstratigrafi. Sveriger Geologiska Undersökning, Arsbok 14 (1920), 1-100.

Heureux, I. L'2018. Diagenetic Self-Organization and Stochastic Resonance in a Model of Limestone-Marl Sequences. Geofluids 2018, 1-18. DOI 10.1155/2018/4968315

HiLGEN, F.J. et al. 2003. Integrated stratigraphy and astronomical tuning of the Serravallian and lower Tortonian at Monte dei Corvi (Middle-Upper Miocene, northern Italy). Palaeogeography, Palaeoclimatology, Palaeoecology 199(3), 229-264. DOI 10.1016/S0031-0182(03)00505-4

JePPSSON, L. 1983. Silurian conodont faunas from Gotland. Fossils and Strata 15, 121-144.

Kerans, C., Hurley, N.F. \& Playford, P.E. 1986. Marine Diagenesis in Devonian Reef Complexes of the Canning Basin, Western Australia, 357-380. In Schroeder, J.H. \& Purser, B.H. (eds) Reef Diagenesis. Springer, Berlin \& Heidelberg. DOI 10.1007/978-3-642-82812-6_18

Kershaw, S. 1994. Classification and geological significance of biostromes. Facies 31(1), 81-91. DOI 10.1007/BF02536934

Langereis, C.G. \& Hilgen, F.J. 1991. The Rossello composite: a Mediterranean and global reference section for the Early to early Late Pliocene. Earth and Planetary Science Letters 104(2), 211-225. DOI 10.1016/0012-821X(91)90205-V

LeE, D.J. \& Elias, R.J. 1991. Mode of growth and life-history strategies of a Late Ordovician halysitid coral. Journal of Paleontology 65(2), 191-199. DOI 10.1017/S0022336000020424

Liang, K., Elias, R. \& LeE, D.-J. 2018. Morphometrics, growth characteristics, and phylogenetic implications of Halysites catenularius (Tabulata, Silurian, Estonia). Journal of Paleontology 93(2), 215-231. DOI 10.1017/jpa.2018.73

Liang, K., Elias, R., Choh, S.-J., Lee, D.-C. \& Lee, D.J. 2016. Morphometrics and paleoecology of Catenipora (Tabulata) from the Xiazhen Formation (Upper Ordovician), Zhuzhai, South China. Journal of Paleontology 90(6), 1027-1048. DOI 10.1017/jpa.2016.60

Long, D. \& Copper, P. 1987. Stratigraphy of the Upper Ordovician upper Vaureal and Ellis Bay formations, eastern Anticosti Island, Quebec. Canadian Journal of Earth Sciences 24(9), 1807-1820. DOI 10.1139/e87-172

MA, T.Y.H. 1934. On the seasonal change of growth in a reef coral, Favia speciose (Dana), and the watertemperature of the Japanese seas during the latest geological times. Proceedings of the Imperial Academy 10, 353-356.

DOI 10.2183/pjab1912.10.353 
MA, T.Y.H. 1958. The relation of growth rate of reef corals to surface temperature of sea water as basis for study of causes of diastrophisms investigating evolution of life. Research on the Past Climate and Continental Drift. 60 pp. The first series of private research publication, Vol. 14. World Book Co., Taipei, Taiwan.

Manten, A.A. 1962. Some Middle Silurian reefs of Gotland. Sedimentology 1(3), 211-234.

DOI 10.1111/j.1365-3091.1962.tb00456.x

Manten, A.A. 1971. Silurian reefs of Gotland. Developments in Sedimentology 13, 1-539.

Mazzullo, S.J. 1971. Length of the Year during the Silurian and Devonian Periods: New Values. GSA-Bulletin 82(4), 1085-1086. DOI 10.1130/0016-7606(1971)82[1085:LOTYDT]2.0.CO;2

Mõtus, M.-A. \& KlaAmann, E. 1999. The halysitid coral genera Halysites and Cystihalysites from Gotland, Sweden. GFF 121(2), 81-90. DOI 10.1080/11035899901212081

MunNeCKE, A. 1997. Bildung mikritischer Kalke im Silur auf Gotland. Courier Forschungsinstitut Senckenberg 198, $1-131$.

Munnecke, A. \& Samtleben, C. 1996. The Formation of Micritic Limestones and the Development of Limestone-Marl Alternations in the Silurian of Gotland, Sweden. Facies 34, 159-176. DOI 10.1007/BF02546162

Munnecke, A., Westphal, H., Reijmer, J.J.G. \& Samtleben, C. 1997. Microspar development during early marine burial diagenesis: A comparison of Pliocene carbonates from the Bahamas with Silurian limestones from Gotland (Sweden). Sedimentology 44, 977-990.

DOI 10.1111/j.1365-3091.1997.tb02173.x

Nield, E.W. 1982. The earliest gotland reefs: Two bioherms from the Lower Visby Beds (Upper Llandovery). Palaeogeography, Palaeoclimatology, Palaeoecology 39(1), 149-164. DOI 10.1016/0031-0182(82)90078-5

Nohl, T., JarochowsKa, E. \& Munnecke, A. (2019). Revealing the genesis of limestone-marl alternations: a taphonomic approach. Palaios 34(1), 15-31. DOI 10.2110/palo.2018.062

Puetz, S.J., Prokoph, A. \& Borchardt, G. 2016. Evaluating alternatives to the Milankovitch theory. Journal of Statistical Planning and Inference 170, 158-165.

DOI 10.1016/j.jspi.2015.10.006

Read, J.F., Osleger, D. \& Elrick, M. 1991. Two-dimensional modelling of carbonate ramp sequences and component cycles, 473-488. In Franseen, E.K., Wamey, W.L., Kendall, C.G.ST.C. \& Ross, W.C. (eds) Sedimentary Modeling: Computer Simulations and Methods for Improved Parameter Definition. Kansas Geological Survey, Bulletin 233.

RIDING, R. 2002. Structure and composition of organic reefs and carbonate mud mounds: concepts and categories. EarthScience Reviews 58(1), 163-231. DOI 10.1016/S0012-8252(01)00089-7

SAdLeR, P.M. 1981. Sediment Accumulation Rates and the Completeness of Stratigraphic Sections. The Journal of Geology 89(5), 569-584. DOI 10.1086/628623

SADLER, P.M. 1994. The expected duration of upward-shallowing peritidal carbonate cycles and their terminal hiatuses. GSA-Bulletin 106(6), 791-802.

DOI 10.1130/0016-7606(1994)106<0791:TEDOUS >2.3.CO;2

Samtleben, C. \& Munnecke, A. 1999. Reefmounds im unteren Wenlock auf Gotland: Beispiele früher Korallenriffe. Meyniana 51, 77-94.

Samtleben, C., Munnecke, A. \& Bickert, T. 1996. The Silurian of Gotland (Sweden): facies interpretation based on stable isotopes in brachiopod shells. Geologische Rundschau 85, 278-292. DOI 10.1007/s005310050074

SAnders, D. 2004. Potential significance of syndepositional carbonate dissolution for platform banktop aggradation and sediment texture: a graphic modeling approach. Austrian Journal of Earth Sciences 95-96, 71-79.

Schlager, W. 2005. Carbonate Sedimentology and Sequence Stratigraphy. SEPM Concepts in Sedimentology and Paleontology 8, 1-200. DOI 10.2110/csp.05.08.0001

Schlager, W., Marsal, D., Van der Geest, P.A.G. \& Sprenger, A. 1998. Sedimentation Rates, Observation Span, and the Problem of Spurious Correlation. Mathematical Geology 30(5), 547-556. DOI 10.1023/A:1021742228242

Scrutton, C.T. 1965. Periodicity in Devonian coral growth. Palaeontology 7(4), 552-558.

Scrutton, C.T. 1998. The Palaeozoic corals, II: Structure, variation and palaeoecology. Proceedings of the Yorkshire Geological Society 52, 1-57. DOI 10.1144/pygs.52.1.1

Scrutton, C.T. \& Powell, J.H. 1980. Periodic development of dimetrism in some favositid corals. Acta Palaeontologica Polonica 25, 477-491.

SpJeldnAEs, N. 2002. Silurian bryozoans from Gotland fossilized in galena and sphalerite. gff 124, 27-33.

DOI 10.1080/11035890201241027

STEL, J. 1978. Environment and quantitative morphology of some Silurian tabulates from Gotland. Scripta Geologica 47, $1-75$.

Strasser, A., Hilgen, A. \& Heckel, P.H. 2006. Cyclostratigraphy - Concepts, definitions, and applications. Newsletters Stratigraphy 42(2), 75-114.

DOI 10.1127/0078-0421/2006/0042-0075

Sujkowski, Z.L. 1958. Diagenesis. American Association of Pelloleum Geologists Bulletin 42(11), 2692-2717. DOI 10.1306/0BDA5C09-16BD-11D7-8645000102C1865D

Tucker, M.E., Gallagher, J. \& Leng, M.J. 2009. Are beds in shelf carbonates millennial-scale cycles? An example from the mid-Carboniferous of northern England..... Sedimentary Geology 214(1), 19-34. DOI 10.1016/j.sedgeo.2008.03.011

van ANDEL, T.H. 1981. Consider the incompleteness of the geological record. Nature 294(5840), 397-398.

DOI $10.1038 / 294397 \mathrm{a} 0$

WestPhal, H. 2006. Limestone-marl alternations as environmental archives and the role of early diagenesis: a critical review. International Journal of Earth Sciences 95, 947-961. DOI 10.1007/s00531-006-0084-8

Westphal, H., Hilgen, F. \& Munnecke, A. 2010. An assessment of the suitability of individual rhythmic carbonate successions for astrochronological application. Earth-Science Reviews 99(1), 19-30. DOI 10.1016/j.earscirev.2010.02.001 
Westphal, H., Lavi, J. \& Munnecke, A. 2015. Diagenesis makes the impossible come true: intersecting beds in calcareous turbidites. Facies 61(2), 1-3.

DOI 10.1007/s10347-015-0427-7

Westphal, H., Munnecke, A., Böhm, F. \& Bornholdt, S. 2008. Limestone-marl alternations in epeiric sea settings - witnesses of environmental changes, or of rhythmic diagenesis? Geological Association of Canada Special Paper 48, $1-20$.
Wood, R.A. 1999. Reef Evolution. 414 pp. Oxford University Press, Oxford.

Wright, V.P. 1994. Early Carboniferous carbonate systems: an alternative to the Cainozoic paradigm. Sedimentary Geology 93(1), 1-5. DOI 10.1016/0037-0738(94)90025-6

Young, G.A. \& Kershaw, S. 2005. Classification and controls of internal banding in Palaeozoic stromatoporoids and colonial corals. Palaeontology 48(3), 623-651.

DOI 10.1111/j.1475-4983.2005.00480.x 